\title{
Long-term scenarios of mercury budgeting and exports for a Mediterranean hot spot (Marano-Grado Lagoon, Adriatic Sea)
}

\author{
Donata Canu*, Ginevra Rosati \\ OGS-National Institute of Oceanography and Experimental Geophysics, Borgo Grotta Gigante 42 c, Sgonico, Trieste, Italy
}

\section{A R T I C L E I N F O}

\section{Article history:}

Received 1 March 2016

Received in revised form

7 October 2016

Accepted 17 December 2016

Available online $\mathrm{xxx}$

\section{Keywords:}

Mercury

Modelling

Lagoon

Budget

WASP7

Scenario analysis

Sediment

Climate

\begin{abstract}
A B S T R A C T
The Marano-Grado Lagoon (MGL) is extensively contaminated by mercury (Hg) from local sources and long-term (500 years) tidally delivered inputs from the Idrija $\mathrm{Hg}$ mine (Slovenia) through Isonzo River suspended loads.

A multibox WASP-7 (Water Analysis Simulation Program) model was used to simulate the long-term dynamics of the mercury cycle in the MGL.

Scenario simulations were used to compute changes in the system over 100 years. Present and future $\mathrm{Hg}$ concentrations in water, sediment, and $\mathrm{Hg}$ budgets were compared, including evasion and $\mathrm{MeHg}$ inputs to the Mediterranean Sea, based on climate changes and mercury capping in tributary rivers.

Using the Ref baseline scenario, the model computes a general decrease in $\mathrm{Hg}_{\mathrm{T}}$ of $13 \%$ in the water column and of $80 \%$ in sediment and a strong MeHg increase in sediment $(+73 \%)$. The net sea export of $\mathrm{Hg}_{\mathrm{T}}$ decreases by $57 \%$ to up to $48 \mathrm{~kg} / \mathrm{y}$ while MeHg increases by $10 \%$ to up to $0.63 \mathrm{~kg} / \mathrm{y}$.

The lagoon sediment recovery time of $\mathrm{Hg}_{\mathrm{T}}$ up to a target level of $0.3 \mathrm{mg} / \mathrm{kg}$ is computed over 570 years for surface sediments (1750 for subsurface sediments). When removing $\mathrm{Hg}$ from boundaries, the same target value for surface sediments is reached within 110 years.
\end{abstract}

(c) 2016 Elsevier Ltd. All rights reserved.

\section{Introduction}

Mercury is a persistent pollutant of global concern that can accumulate in organisms and that can have adverse health effects. Its presence is mainly a result of past human activities such as mining and industrial dumping that have severely altered the state of mercury concentrations in several transitional systems worldwide. A SCOPUS abstract search based on keywords "mercury", "contamination", and "estuaries" retrieved 153 papers published from 1985, 65 of which are focused on "lagoons". The number of studied sites and their global distributions highlight the relevance of this issue also because estuarine and transitional environments play a crucial role in the production of $\mathrm{MeHg}$, a central driver of mercury bioaccumulation in pelagic organisms (Balcom et al., 2015).

The quantification of mercury export contributions from coastal lagoons and estuaries is, therefore, relevant for the assessment of mercury budgets at the global and regional scales. Several budget

\footnotetext{
* Corresponding author.

E-mail address: dcanu@inogs.it (D. Canu).
}

analysis and modelling efforts are being pursued to this end to evaluate and inter-compare $\mathrm{Hg}$ fluxes such as evasion fluxes (Sharif et al., 2013), transfer to food webs (Balcom et al., 2015), riverine inputs (Amos et al., 2014), and transfer to seas and oceans (Zagar et al., 2006; Pato et al., 2008; Bloom et al., 2004; Canu et al., 2012; Melaku Canu et al., 2015 Sprovieri et al., 2011).

Mathematical models are also suitable tools for addressing longterm trajectories under different conditions, including changes in boundary inputs and climate changes (Harley et al., 2006). Scenario analyses are often used to explore system trends and responses according to different assumptions based on direct and indirect effects of human interventions, explore long term trends under semi-stationary conditions (e.g., climate change effects on marine biogeochemistry (Cossarini et al., 2008; Lazzari et al., 2013; Solidoro et al., 2010) or on persistent pollutants (Dalla Valle et al., 2007)) and explore the effectiveness of management responses (Canu et al., 2010; Melaku Canu et al., 2001; Thompson and Flower, 2009).

In this work, a mercury model already formulated and tested for the Marano-Grado Lagoon (Melaku Canu et al., 2015) is used to evaluate long-term mercury contamination trends in the lagoon under alternative scenarios. 
The Marano-Grado Lagoon (Italy) is a coastal lagoon in the Mediterranean Sea (Fig. 1) of roughly $160 \mathrm{~km}^{2}$ that receives freshwater inputs from rivers and marine inputs from the Northern Adriatic Sea. Tidally driven water exchange with the Adriatic Sea is bidirectional and occurs through six inlets (i.e., Lignano, S. Andrea, Buso, Morgo, Grado and Primero, Fig. 1) after which the 6 subbasins were named (Dorigo, 1965). Riverine effects, given the strong seasonal variations in salinity, have been identified in the western section of the lagoon while the eastern section is more marine driven (Ferrarin et al., 2010).

The lagoon is a hot spot of mercury contamination (Covelli et al., 2012) as a consequence of mining and industrial activities that have caused the release of large amounts of mercury compounds into the environment. As $\mathrm{Hg}$ is pervasively present in the lagoon sediment, diffuse reclamation is not feasible. The historical source of $\mathrm{Hg}$ is the Idrija cinnabar mine (Slovenia), which has been estimated to have released 37,000 tons of $\mathrm{Hg}$ over 500 years of activity (Dizdarevič, 2001). The $\mathrm{Hg}$ extraction in the Idrija mine reached a maximum at the end of the XIX century, followed by a gradual decrease in the following decades. The ore dumping in the environment followed a similar pattern, until 1970, when the direct dumping into the river was finally prohibited. At the end of the 1980's the Hg production was $1 / 10$ of the peak's production reached in 1890. (Gnamuš and Horvat, 1999; Car and Dizdareviĉ, 2004). This material has been transported by the Soča-Isonzo River and delivered to the Gulf of
Trieste (Zagar et al., 2006). While most particulate Hg deposits are found close to riverbanks, prevailing currents also drive suspended and dissolved materials further south towards the Marano-Grado Lagoon. Currently, average sediment concentrations reach 721 ppm downstream from the mine (Gosar and Teršič, 2015), $40 \mathrm{ppm}$ at the Soča-Isonzo River mouth (Gosar and Teršič, 2015), $1 \mathrm{ppm}$ in the central Gulf of Trieste (Faganeli et al., 2014) and $4.4 \mathrm{ppm}$ in the Marano-Grado Lagoon, thus ranging from 0.6 to $10 \mathrm{ppm}$ (Acquavita et al., 2012). Higher levels in the sediment of the Marano-Grado Lagoon compared to those in the open Gulf of Trieste are attributable to the following different processes: 1) the direction of currents; 2) the lagoon as a more confined environment; and 3) the presence of an additional source of contamination.

In addition to inputs from the mining site, the lagoon has been receiving direct inputs of $\mathrm{Hg}$ through its Aussa-Corno River tributary from a former chlor-alkali plant that has dumped roughly 190 tons of $\mathrm{Hg}$ over 45 years (Acquavita et al., 2012). Historically, the lagoon has acted as a sink for $\mathrm{Hg}$ transported from the Gulf of Trieste and the chlor-alkali plant, accumulating roughly 251 tons of $\mathrm{Hg}$ in its sediments (Covelli et al., 2012). A mass balance study showed that under present conditions, outputs from the lagoon exceed inputs (Melaku Canu et al., 2015), and, thus, in the longterm, a natural decontamination of $\mathrm{Hg}$ stored in the lagoon's environmental compartment is expected. Here, we explore the time scale for the natural recovery of sediment and the relevance of
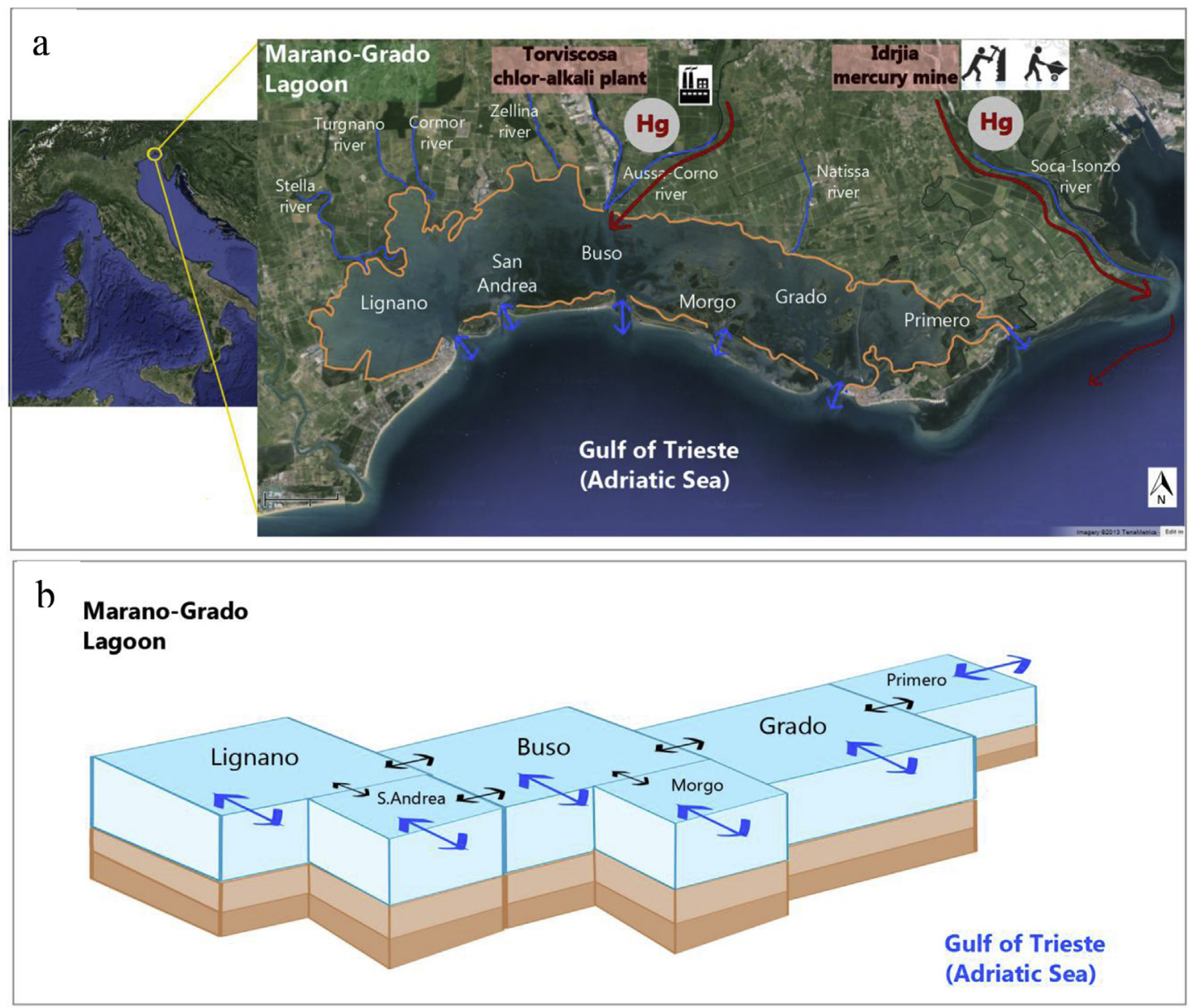

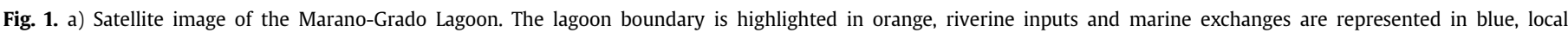

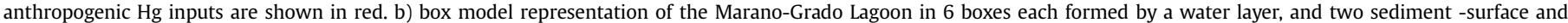

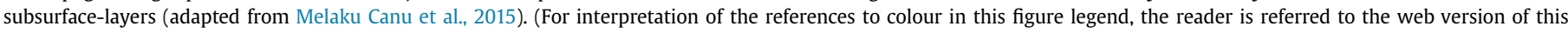
article.) 
different inputs and forcings to mercury dynamics in the lagoon using different future scenarios to take into account effects of environmental variability and climate change projections on mercury biogeochemistry dynamics and fluxes.

\section{The model structure and its application}

The dynamic and spatially resolved water quality model was applied using the Water Quality Analysis Simulation Programme (WASP7, v7.3) as described in Melaku Canu et al. (2015).

As described by Wool et al. (2001), the model simulates the dynamic evolution of three mercury species over time (divalent inorganic mercury ( $\mathrm{Hg}(\mathrm{II}))$, methylmercury ( $\mathrm{MeHg}$ ) and elemental mercury $\left(\mathrm{Hg}^{0}\right)$ ) and three solids types (silt, sand, and biotic solids) in a discretised box system.

The overall equation for the mass conservation of generic state variable $C$ (representative of a mercury species) in each water box includes terms for advection ( $\mathrm{U}$ in $\mathrm{m} / \mathrm{sec}$ ) and diffusion $\left(\mathrm{E}\right.$ in $\mathrm{m}^{2} /$ day) in the three dimensions ( $x, y, z)$ and reads as Eq. (1.1). The equation also accounts for the biogeochemical transformation of $\mathrm{Hg}$ species $\left(\mathrm{S}_{\mathrm{rx}}\right.$ in $\mathrm{g} / \mathrm{m}^{3}$ day), direct and diffusive loads $\left(\mathrm{S}_{\mathrm{L}}\right.$ in $\mathrm{g} / \mathrm{m}^{3}$ day), and exchanges with boundaries or sediment $\left(S_{B}\right.$ in $g / m^{3}$ day):

$$
\begin{aligned}
\frac{d c}{d t}= & \frac{d\left(U_{x} C\right)}{d x}-\frac{d\left(U_{y} C\right)}{d y}-\frac{d\left(U_{z} C\right)}{d z}+\frac{d}{d x}\left(E x \frac{d C}{d x}\right)+\frac{d}{d y}\left(E_{y} \frac{d C}{d y}\right) \\
& +\frac{d}{d z}\left(E_{z} \frac{d C}{d z}\right)+S_{L}+S_{B}+S_{r x}
\end{aligned}
$$

Advective and diffusive processes are responsible for the exchange of water, particles and solutes between water boxes and between boxes and their boundary systems including the atmosphere, deep sediments, and marine boundaries. While transported, $\mathrm{Hg}$ species are partitioned between dissolved and particulate phases.

$\mathrm{Hg}^{0}$ is assumed only in its dissolved form while $\mathrm{Hg}$ (II) and $\mathrm{MeHg}$ are modelled as sorbing to sand, silts, and biotic solids and as being complex with dissolved organic carbon (DOC).

The model addresses the bioaccumulation of mercury in biota simply by dynamically modelling primary production and degradation processes of the 'organic solids' variable, which is subjected to production and dissolution. Production (eq. (1.2)) is parameterized based on a rate $\mathrm{k}_{\mathrm{pp}}\left(\mathrm{g} / \mathrm{m}^{3} \mathrm{~d}\right)$ corrected by the temperature value $\left(\theta_{P P}^{T-20} * X_{t}\right)$ and it can be variable in space and time (using the $X_{b o x}$ multiplier). In a similar way, degradation is parameterized based on a rate $k_{d e g}(1 / d)$ that can be temperature-corrected and that is multiplied by the concentration of organic solids $\left(\mathrm{C}_{\mathrm{OM}}\right)$ in that box:

Production $=k_{P P} \cdot \theta_{P P}^{T-20} \cdot X_{t} \cdot X_{b o x} \quad\left[\frac{g d w}{m^{3} d a y}\right]$

Degradation $=k_{\text {deg }} \cdot \theta_{\text {deg }}^{T-20} \cdot X_{t} \cdot X_{b o x} \cdot C_{O M}\left[\frac{g d w}{m^{3} d a y}\right]$

The model dynamically simulates transformations $\left(S_{\mathrm{rx}}\right.$, eq. (1.1)) by means of first order rate constants. The modelled transformation processes are graphically presented in Fig. 2 and include the following: the photo-oxidation of $\mathrm{Hg}(0)$ into $\mathrm{Hg}(\mathrm{II})$ in water, the photo-reduction of $\mathrm{Hg}(\mathrm{II})$ into $\mathrm{Hg}(0)$ in water, the photodegradation of $\mathrm{MeHg}$ into $\mathrm{Hg}(0)$ in water, the biotic methylation of $\mathrm{Hg}(\mathrm{II})$ into $\mathrm{MeHg}$ in water and sediments, the biotic demethylation of $\mathrm{MeHg}$ into $\mathrm{Hg}(\mathrm{II})$ in water and sediments.

Mercury: 1) is transported through water fluxes in dissolved and particulate forms; 2) is diffused in interface water/sediment in its dissolved form; 3 ) volatilises at the water/air interface; and 4) is

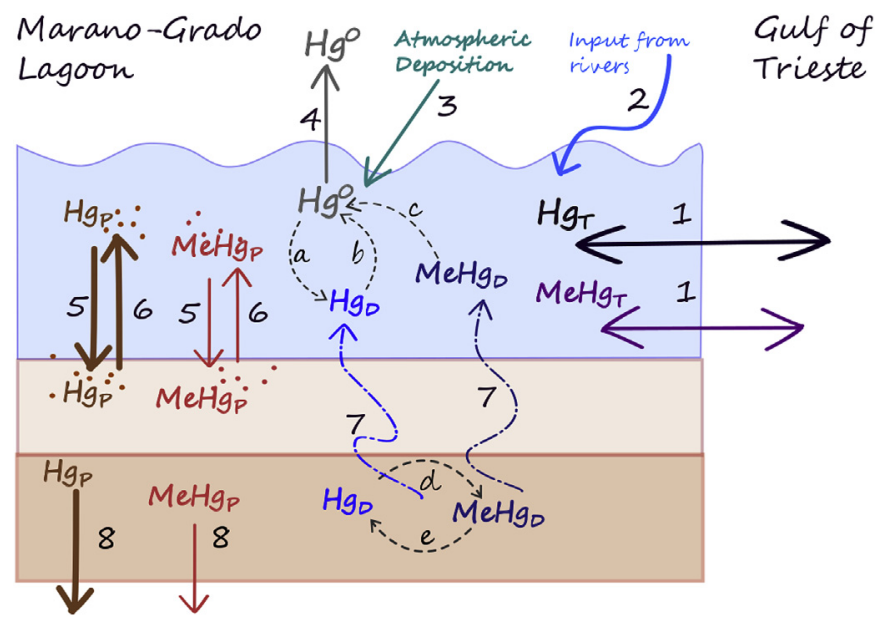

Fig. 2. Graphycal representation of the mercury model. $\mathrm{Hg}_{\mathrm{T}}$ is total $\mathrm{Hg}$ $\left(\mathrm{Hg}^{\mathrm{II}}+\mathrm{Hg}^{\mathrm{O}}+\mathrm{MeHg}\right.$ in dissolved and particulate phase), $\mathrm{MeHg}_{\mathrm{T}}$ is total $\mathrm{MeHg}$ (dissolved and particulate phase of $\mathrm{MeHg}$ ), $\mathrm{Hg}_{\mathrm{p}}$ and $\mathrm{MeHg}_{\mathrm{p}}$ are particulate-bounded $\mathrm{Hg}^{\mathrm{II}}$ and $\mathrm{MeHg}$, whilst $\mathrm{Hg}_{\mathrm{D}}$ and $\mathrm{MeHg}_{\mathrm{D}}$ are the dissolved forms of $\mathrm{Hg}^{\mathrm{II}}$ and $\mathrm{MeHg}$. Numbers 1-8 indicate transport processes (1-Exchange with the Sea, 2-Input from rivers, 3Atmospheric deposition, 4-Volatilization, 5-Deposition, 6-Resuspension, 7-Pore water diffusion, 8-Burial) letters a-e indicate transformation processes (a-Photo-oxidation, $b$ Photo-reduction, c-Photo-demethylation, d-Methylation, e-Demethylation) (adapted from Melaku Canu et al., 2015).

sedimented or resuspended at the sediment/water interface in particulate from.

$\mathrm{Hg}^{0}$ exchange between surface water boxes and the overlying atmosphere is dependent on water and air concentrations of elemental $\mathrm{Hg}\left(\mathrm{Hg}^{0}{ }_{w}\right.$ and $\mathrm{Hg}^{0}{ }_{\text {atm }}$ in $\left.\mathrm{mg} / \mathrm{L}\right)$ and temperatures following Henry's law. $\mathrm{Hg}$ species exchange at the sediment layer/ water interface is controlled by deposition and resuspension rates of organic and inorganic solids and pore water diffusion.

Resuspension and the settling of mercury species bounded to organic and inorganic solids are simulated dynamically in time at the sediment/water interface as a function of flow velocity, shear stress, and particle size. As velocity decreases the shear stress along the underlying sediment decreases, thereby decreasing the suspension velocity and increasing the settling velocity.

The lagoon system is represented as an 18-box system that are divided into 6 sub-basins (Lignano, S. Andrea, Buso, Morgo, Grado and Primero) according to the hydraulic zonation configuration proposed by Dorigo (1965). Each sub-basin is represented in the model as including the following three layers: a water layer, a surface sediment layer ( $0-2 \mathrm{~cm}$ depth) and a subsurface sediment layer (3-10 cm depth). Sub-basins are interconnected as shown in Fig. $1 \mathrm{~b}$, and each is connected to the marine and overlying atmospheric boundaries. Three of them (Lignano, Buso and Grado) are connected to three additional water boxes representing their tributary rivers. Exchanges of water, suspended particulates and $\mathrm{Hg}$ species occur at each intersection between sub-basins and boundaries.

Water transport between the 6 lagoon water boxes and with marine boundaries is simulated using prescribed water fluxes. Water fluxes were computed on purpose using a validated finite element hydrodynamic model of the Marano-Grado Lagoon (Ferrarin et al., 2010) forced with a 3-year set-up (2009-2011) that includes the following: water levels at marine inlets, meteorological forcings (hourly solar irradiance, precipitation, wind speed and direction) and riverine discharge.

The dynamical evolution of mercury species is modelled as a function of meteo-climatic data and is included in the model as daily forcing functions of light intensity, daylight hours, and 
monthly water temperature. The model can, therefore, reproduce the temporal variability of methylation-demethylation and photoreactions (photo-demethylation, photo-reduction and photooxidation) while the partitioning of mercury species $\left(\mathrm{Hg}_{\mathrm{T}}\right.$ and $\mathrm{MeHg}$ ) occurs at constant rates in time and space.

Transport coefficients and transformation rate constants were selected according to studies conducted in the Marano-Grado Lagoon (Covelli et al., 2008; by Hines et al., 2012) and other similar environments when local information was not available (Hammerschmidt and Fitzgerald, 2004; Monperrus et al., 2007; Rothenberg et al., 2008; Sorokin et al., 1996; Whalin et al., 2007; Vost et al., 2012; US EPA, 1988, US EPA, 2009).

Marine exchange with the Adriatic Sea was simulated through the advection of dissolved and particulate $\mathrm{Hg}\left(\mathrm{Hg}_{\mathrm{D}}\right.$ and $\left.\mathrm{Hg}_{\mathrm{P}}\right)$ and $\mathrm{MeHg}\left(\mathrm{MeHg}_{\mathrm{D}}\right.$ and $\mathrm{MeHg}_{\mathrm{P}}$ ) according to the prescribed water flux variable in time and space and according to monthly variable concentrations of particulate matter (SPM). This information was derived from our dataset (Horvat et al., 2003; Regione FVG, 2013) as explained in Melaku Canu et al., 2015).

River inputs are given as unidirectional inputs of water, as dissolved and particulate $\mathrm{Hg}$ and as $\mathrm{MeHg}$. $\mathrm{Hg}$ is input at the atmospheric boundary via deposition using the seasonal values given by Žagar et al. (2007).

The model was set up in agreement with Melaku Canu et al. (2015) using the three-year scenario set-up for 2009-2011, the time frame for which a complete series of dissolved mercury concentrations in the lagoon water and meteorological data are available. The model was initialised using space variable field data of sediment compositions (silt, sand and OC) and mercury sediment concentrations $\left(\mathrm{Hg}_{\mathrm{T}}, \mathrm{HgS}\right.$ and $\mathrm{MeHg}$ ) according to Acquavita et al. (2012). Concentrations in the water column were set to 0. Additional information on the model's implementation; parameter selection methods; and comparisons between experimental data on $\mathrm{Hg}_{\mathrm{D}}$ and deposition, erosion and burial rates are given by Melaku Canu et al. (2015). Despite the model's simple spatial discretization, data comparisons confirm the model's capacity to reproduce the selected processes. Average sediment deposition values, erosion values and burial rates computed from the model based on values of shear stress induced by currents are in agreement with experimental values measured by Bloom et al. (2004) and Covelli et al. (2012).

The baseline scenario, Reference simulation (Ref), was used here to assess the recovery time of surface sediment under the assumption that external conditions remain as they are now (i.e., recursively applying the three-year set-up of forcing and boundary conditions). At the marine boundary, the concentration of dissolved mercury $\left(\mathrm{Hg}_{\mathrm{D}}\right)$ and of mercury bounded to suspended sediments $\left(\mathrm{Hg}_{\mathrm{P}}\right)$ is mainly related to inputs delivered by the Isonzo River (Covelli et al., 2012; Rajar et al., 2000) and discharged into the Adriatic Sea in the Gulf of Trieste (see Fig. 1a). Even though $\mathrm{Hg}_{\mathrm{T}}$ at the marine boundary is expected to decrease in the future, as a consequence of the mine's closure in 1996, according to Covelli et al., 2012 in the short term, such a decrease is unlikely to occur. Gosar (2008) noted that mercury concentrations in river sediments in the Idrijca and Isonzo-(Soca) Rivers have not decreased over the past 15 years since mining activities have stopped due to the extent of historical discharge still present along the rivers banks. Therefore, we applied a precautionary approach by maintaining existing $\mathrm{Hg}_{\mathrm{T}}$ input values throughout the whole simulation. In addition, we explored uncertainties in changes in forcing and boundary conditions by applying the following three additional scenarios: a) the increase in water temperature according to climatic change (CC) scenarios, b) the sea level rise High water Level scenario (HwL) and c) the removal of mercury inputs from the riverine boundaries (NoR). All of these simulations were run for 100 years and then compared.

The CC scenario was applied according to Lazzari et al. (2013), who modelled the effects of climate change on the biogeochemistry of the Mediterranean Sea following the IPCC's SRES A1B scenario conditions (Nakicenovic and Swart, 2000). For 2070-2100, they predicted a warming of Northern Adriatic Sea surface water of $2.5^{\circ} \mathrm{C}$ both in the winter and summer. This temperature increase was, therefore, applied to the water temperature time series while all other forcings and parameters were the same as those used in the Ref simulation.

The HwL scenario was applied by introducing changes in water fluxes in agreement with the results of the hydrodynamic model simulation of a sea level rise scenario. The sea level rise scenario was simulated by increasing sea level values at marine boundaries of $0.315 \mathrm{~m}$ in agreement with Lambeck et al. (2011).

Moreover, the sediment recovery time was assessed through a long-term simulation by running the baseline Ref simulation until surface and subsurface sediment met the legislative limit of $0.3 \mathrm{ppm}$. This result was compared with results obtained from running a simulation that excluded mercury inputs from the Adriatic Sea while setting the sea HgT to 0 as an extreme case of mercury input reduction.

\section{Results}

After 100 years, the Ref simulation shows a general decrease in $\mathrm{Hg}_{\mathrm{T}}$ concentrations along the Lagoon surface (Fig. 3) and subsurface sediments (Fig. 4). The average reduction in the two sediment layers of the whole lagoon is $-63 \%$ with more pronounced decreasing trends found in the Primero $(-86 \%)$ and Morgo $(-93 \%)$ sub-basins.

After an initial increase at the start of the simulation, $\mathrm{MeHg}$ tends to decrease and stabilize with asymptotic behaviour, on average increasing at the end by $43 \%$ in surface sediment and by $1.2 \%$ in the water column as shown in Table 1 . At the end of the simulation, concentrations decrease in S. Andrea and Primero by $-20 \%$ and $-64 \%$ in surface sediments, respectively, and increase in the Lignano, Buso Morgo and Grado sub-basins by $102 \%, 81 \%$, $22 \%$, and $139 \%$, respectively.

MeHg concentrations tend to increase in subsurface sediment (Fig. 4, Table 1), reaching a pseudo-stable value in some sub-basins (S.Andrea, Primero and Morgo) and maintaining an increasing trend towards the end of the simulation for the others.

In response to high frequency signals (e.g., tidal exchanges and solar radiation), $\mathrm{Hg}_{\mathrm{T}}$ concentrations in lagoon water (Fig. 5) show higher levels of intra-annual variability than sediment concentrations. With time evolution, an overall (statistically significant ( $p<0.05$, Wilcoxon rank sum test)) decrease of $-13 \%$ is observed for all sub-basins with minimal decrease found in Primero $(-8 \%)$ and maximum decrease found in Grado (-15\%). Water MeHg increases overall at a statistically significant level $(p<0.05$, Wilcoxon rank sum test) by $11 \%$ in all of the sub-basins.

A scenario analysis was carried out at the sub-basin scale by comparing the evolution of total mercury $\left(\mathrm{Hg}_{\mathrm{T}}\right)$ and methylmercury ( $\mathrm{MeHg})$ concentrations in surface sediments $(0-2 \mathrm{~cm})$, subsurface sediments $(3-10 \mathrm{~cm})$ and the water column as shown in Figs. 3-5. The percentage of the variation in mercury $(\mathrm{Hg})$ concentrations in each scenario with respect to Ref conditions was computed for each sub-basin and then averaged for the whole lagoon as shown in Table 2.

The NoR simulation scenario was explored to address the effect of mercury riverine inputs on the recovery of lagoon sediment. Computed concentrations of the NoR scenario at the end of the 100-year simulation were compared with the Ref, revealing a small decrease in $\mathrm{Hg}_{\mathrm{T}}$ at the surface (Fig. 3) and subsurface sediment 
$\mathrm{Hg}_{\mathrm{T}}$ concentrations in the surface sediment
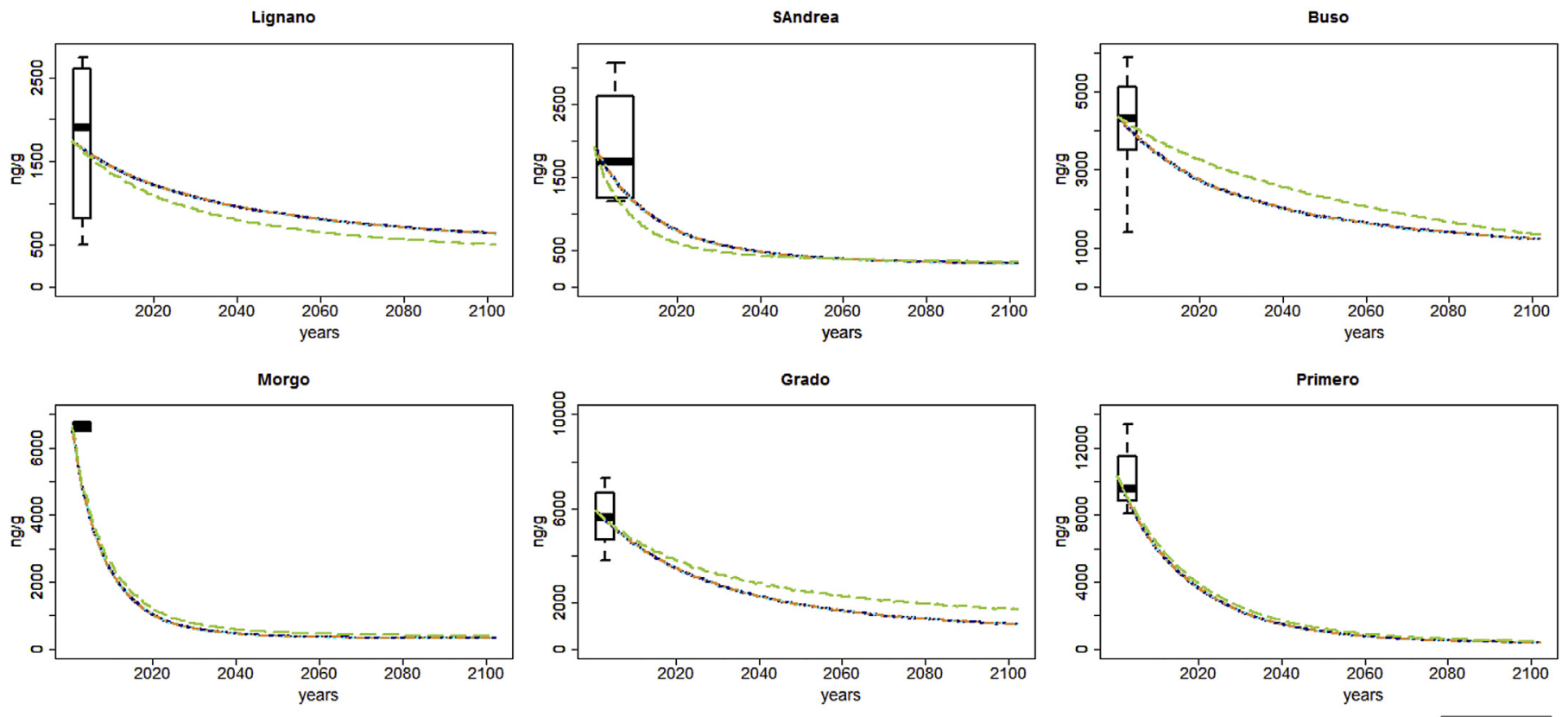

$\mathrm{MeHg}_{\mathrm{T}}$ concentrations in the surface sediment
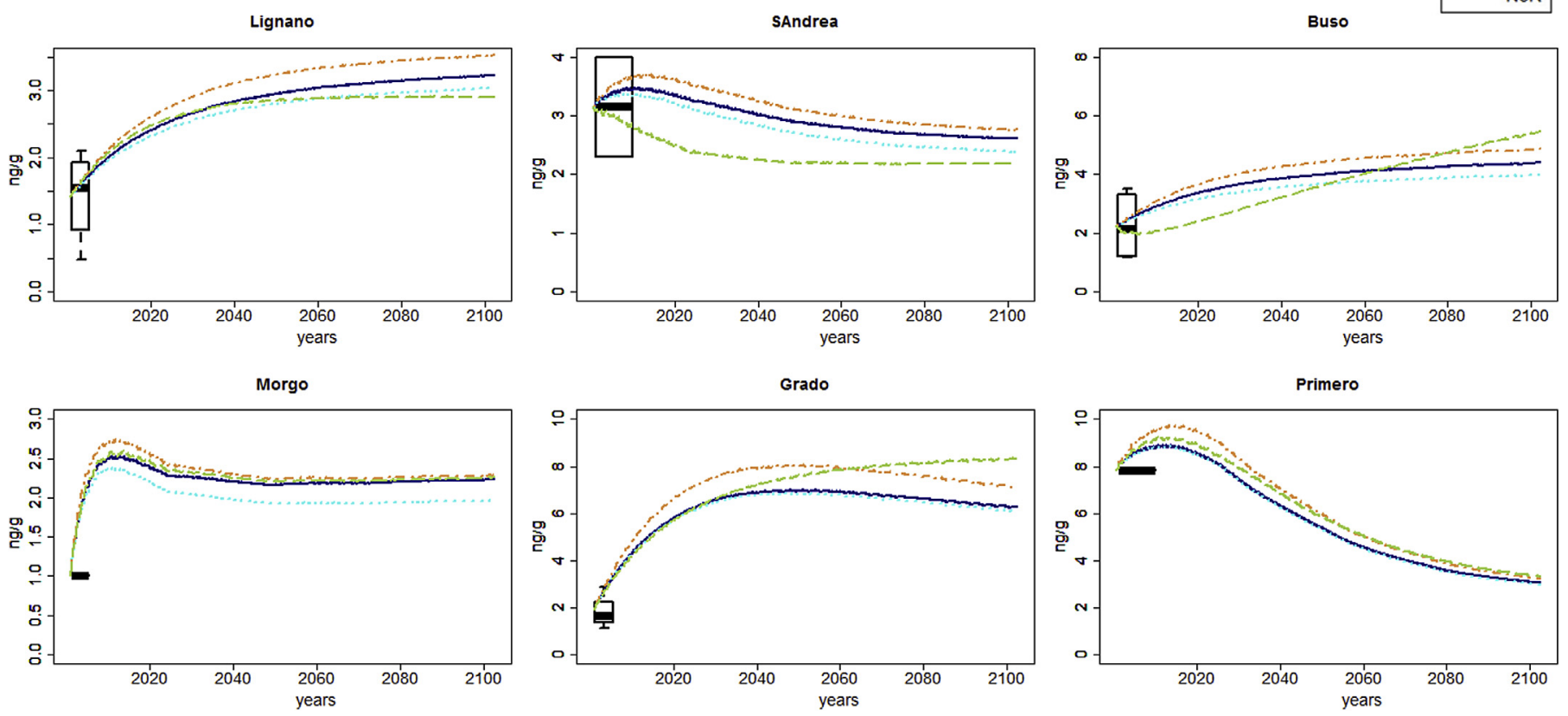

Fig. 3. Time evolution $\mathrm{Hg}_{\mathrm{T}}$ (upper panel) and $\mathrm{MeHg}$ (lower panel) concentrations in surface sediment layers. Box plot: field data.

(Fig. 4 ) of $1.2 \%$ and $0.4 \%$, respectively, and a decrease of $\mathrm{Hg}_{\mathrm{T}}$ in water of $2.6 \%$ as shown in Fig. 5 and Table 2. Effects of the absence of riverine inputs on $\mathrm{MeHg}$ concentrations are more pronounced (Fig. 5), leading to a $-12.5 \%$ reduction in the water column and decreases of $6.6 \%$ and $2.9 \%$ in the surface and subsurface sediment layers, respectively, as shown in Figs. 3 and 4 and Table 2.

Under the CC scenario, an average temperature increase of $2.5^{\circ} \mathrm{C}$ over the whole simulation period has a negligible effect on $\mathrm{Hg}_{\mathrm{T}}$ concentrations (as shown in Fig. 5 and Table 2) with respect to Ref while surface and subsurface sediments slightly increase or decrease depending on sub-basin conditions (as shown in Figs. 3 and 4). Methylation and demethylation processes, however, are more sensitive to temperature changes compared to the other transformation processes (Fig. 2); we, therefore, observed higher MeHg concentrations in the surface (8\%) and subsurface sediments (13\%) in the CC scenario with respect to the Ref. This effect could have been even more significant if the model had taken into account methylation processes occurring in the water column. Under the CC scenario, the transfer of MeHg from sediment to the water column is enhanced due to higher $\mathrm{MeHg}_{\mathrm{D}}$ diffusion rates from pore-water $(+12 \%)$ and higher due to $\mathrm{MeHg}_{\mathrm{P}}$ resuspension rates $(+11 \%)$. This affects the export of MeHg into the Adriatic Sea, which 
$\mathrm{Hg}_{\mathrm{T}}$ concentrations in the sub-surface sediment
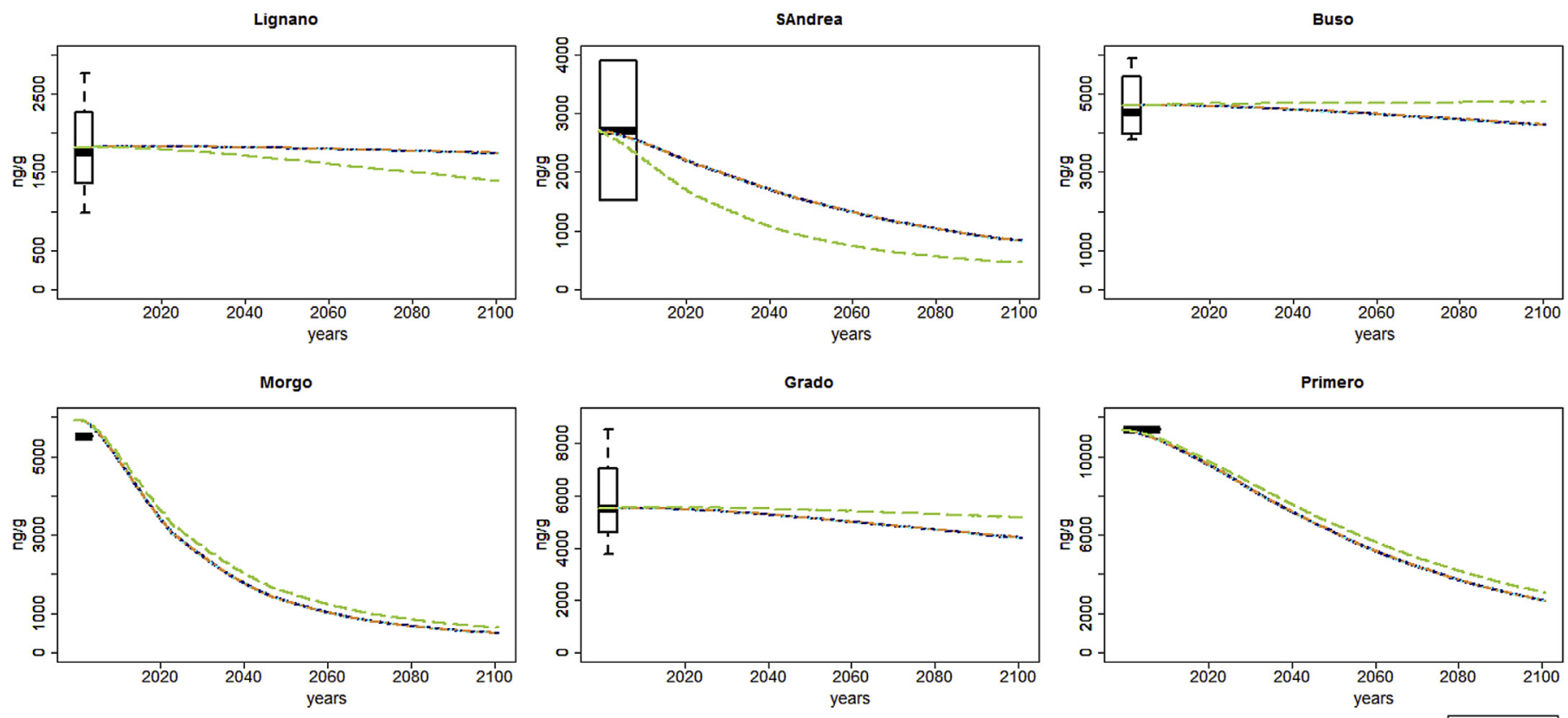

$\mathrm{MeHg}_{\mathrm{T}}$ concentrations in the sub-surface sediment
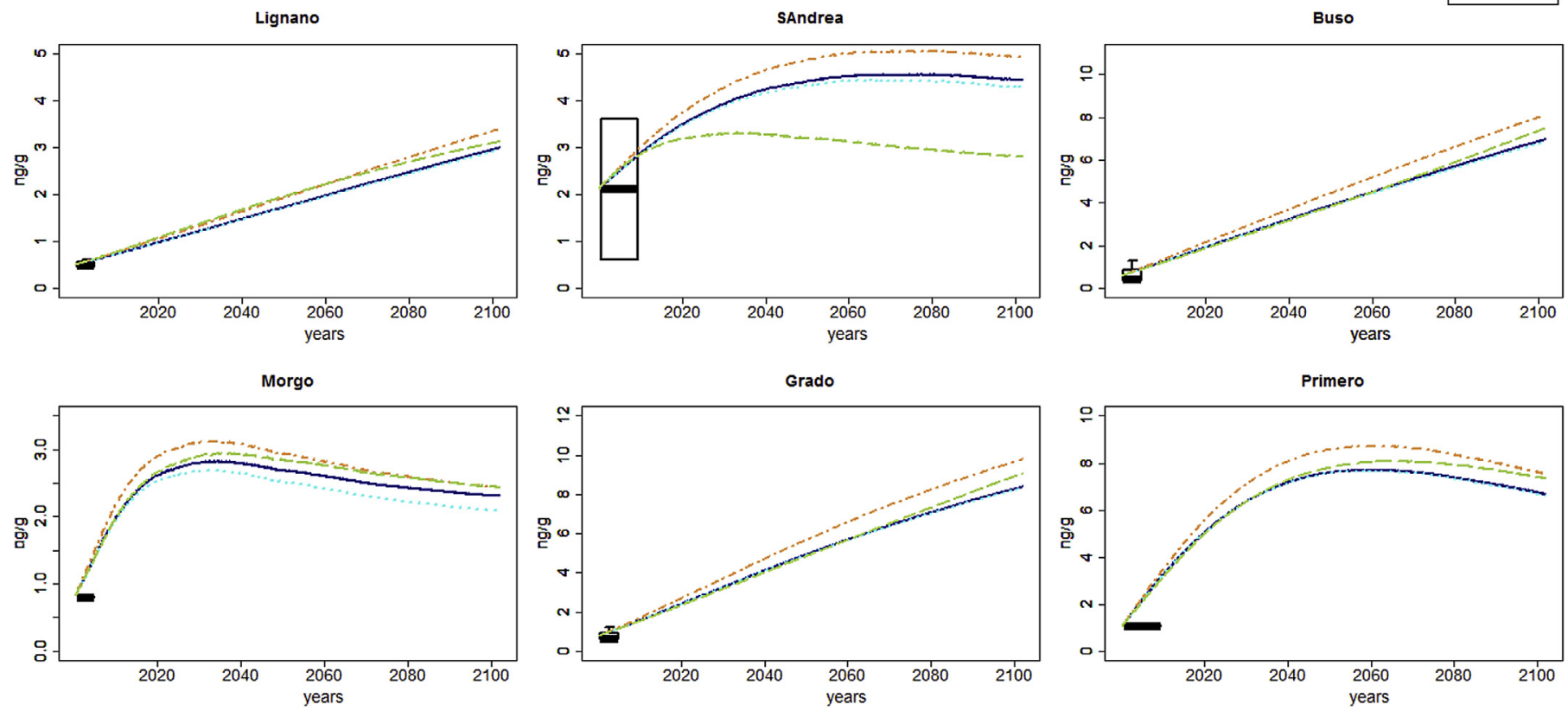

Fig. 4. Time evolution of $\mathrm{Hg}_{\mathrm{T}}$ (upper panel) and $\mathrm{MeHg}$ (lower panel) concentrations in subsurface sediment layers. Box plot: field data.

increases by $2.7 \%$. As a consequence, $\mathrm{MeHg}_{\mathrm{P}}$ burial in deep sediments increases as well $(+11 \%)$. Higher temperatures also affect exchanges between surface water and the atmosphere, causing a $1 \%$

Table 1

Summary of the average percentage of variations (from the initial state) of $\mathrm{Hg}$ species concentrations in water, surface sediment and subsurface sediment by the end of the 100 years simulations scenario (Ref).

\begin{tabular}{lllllll}
\hline Compartment & Water & & \multicolumn{2}{l}{ Surface Sediment } & \multicolumn{2}{l}{ Subsurface Sediment } \\
\hline Depth & Average $1 \mathrm{~m}$ & $0-2 \mathrm{~cm}$ & & $2-10 \mathrm{~cm}$ & \\
Mercury & $\mathrm{Hg}$ & $\mathrm{MeHg}$ & $\mathrm{Hg}$ & $\mathrm{MeHg}$ & $\mathrm{Hg}$ & $\mathrm{MeHg}$ \\
Species & $-13 \%$ & $+1.2 \%$ & $-80 \%$ & $+43 \%$ & $-45 \%$ & $+420 \%$ \\
\hline
\end{tabular}

increase in $\mathrm{Hg}(0)$ evasion. $\mathrm{Hg}_{\mathrm{P}}$ and $\mathrm{Hg}_{\mathrm{D}}$ budget processes are generally less affected than those involving MeHg.

Under the HwL scenario, water circulation in the lagoon intensifies, increasing velocities and consequently increasing $\mathrm{Hg}$ resuspension. As this effect is especially more pronounced in the eastern Primero, Grado and Morgo basins and almost negligible in the western part of the lagoon, contrasting changes in the eastern and western sub-basins are observed. As shown in Fig. 5 and Table 2, a general increase of $\mathrm{Hg}_{\mathrm{T}}$ in water is observed in the whole lagoon with respect to Ref, varying from $15 \%$ in Morgo to $0.5 \%$ in Lignano. A general increase in $\mathrm{Hg}_{\mathrm{T}}$ and $\mathrm{MeHg}$ is observed in sediment and subsurface sediment (up to $58 \%$ and $33 \%$ for Grado 
$\mathrm{Hg}_{\mathrm{T}}$ concentrations in the lagoon waters
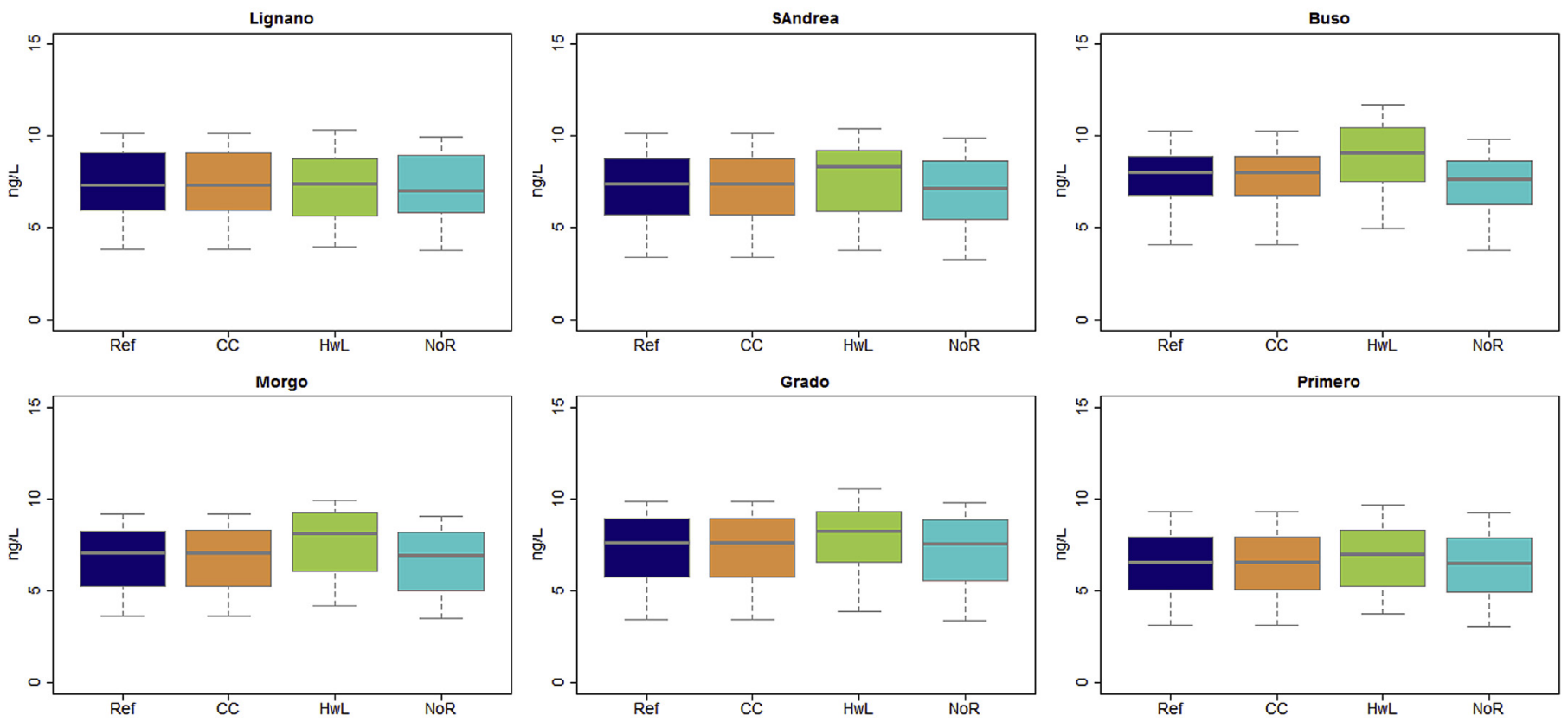

$\mathrm{MeHg}_{\mathrm{T}}$ concentrations in the lagoon water
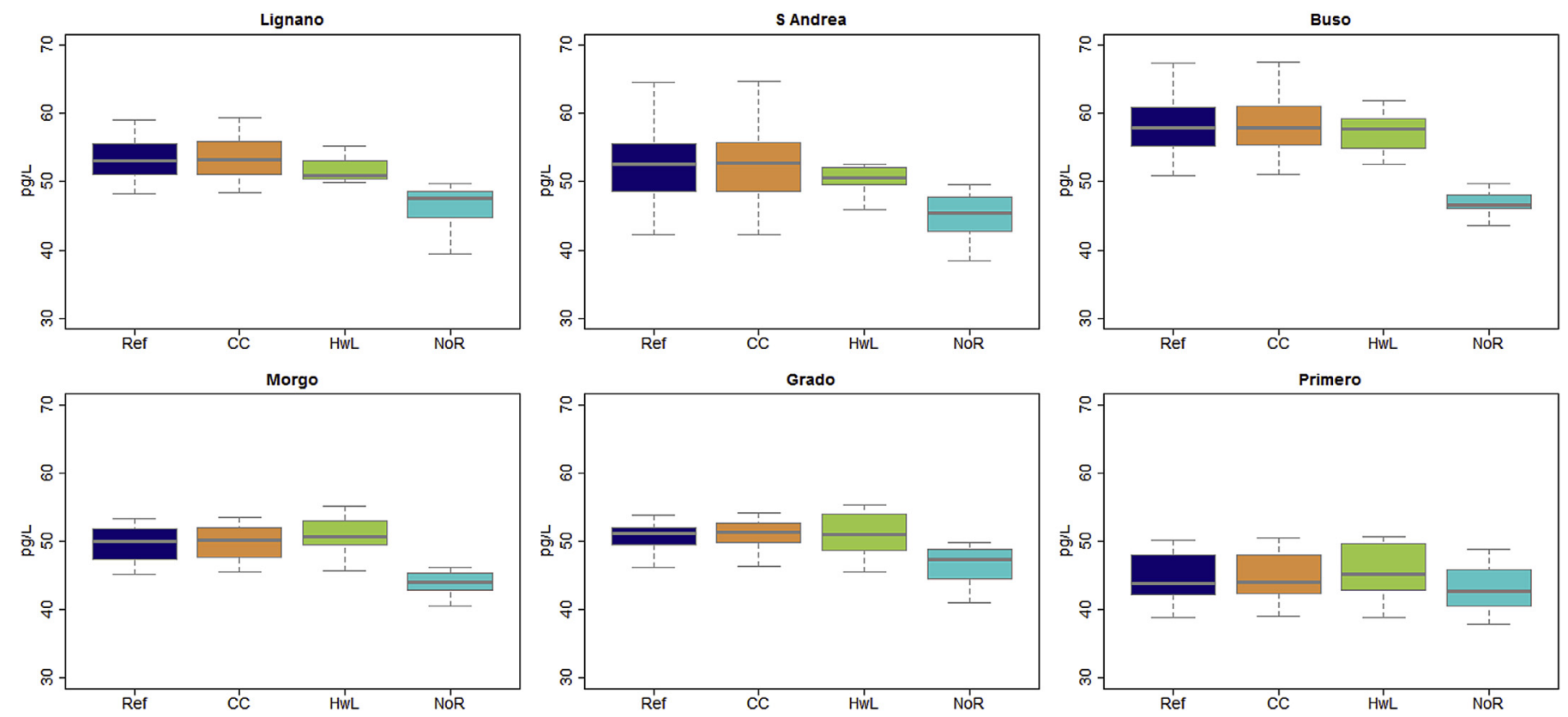

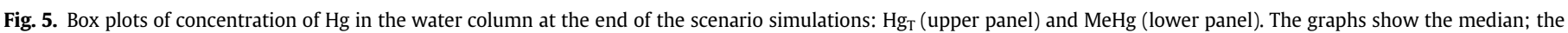
1 st and 3rd quartiles; and minimum and maximum values for each simulation.

Table 2

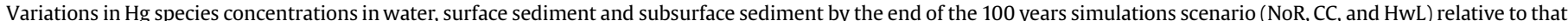
of the Ref scenario by the end of the 100-year period. Values in brackets show the range of variation values computed for the six boxes when they have opposite signs.

\begin{tabular}{|c|c|c|c|c|c|c|}
\hline \multirow{3}{*}{$\frac{\text { Compartment }}{\text { Depth }}$} & \multicolumn{2}{|l|}{ Water } & \multicolumn{2}{|l|}{ Surface Sediment } & \multicolumn{2}{|c|}{ Subsurface Sediment } \\
\hline & \multicolumn{2}{|c|}{ Average $1 \mathrm{~m}$} & \multicolumn{2}{|l|}{$0-2 \mathrm{~cm}$} & \multicolumn{2}{|l|}{$2-10 \mathrm{~cm}$} \\
\hline & $\mathrm{Hg}$ & $\mathrm{MeHg}$ & $\mathrm{Hg}$ & $\mathrm{MeHg}$ & $\mathrm{Hg}$ & $\mathrm{MeHg}$ \\
\hline NoR & $-2,6 \%$ & $-12,5 \%$ & $-1,2 \%$ & $-6,6 \%$ & $-0,4 \%$ & $-2,9 \%$ \\
\hline $\mathrm{CC}$ & $<0.1 \%$ & $0,4 \%$ & $( \pm 0,3 \%) 0,3 \%$ & $8 \%$ & $\begin{array}{l}( \pm 0,2 \%) \\
0,2 \%\end{array}$ & $13 \%$ \\
\hline HwL & $9 \%$ & $(3 \%,-2,3 \%)-0,2 \%$ & $(58 \%,-21 \%) 15,2 \%$ & $(32 \%,-16 \%) 6,8 \%$ & $(26 \%,-45 \%) 2 \%$ & $(26 \%,-5 \%)-0.2 \%$ \\
\hline
\end{tabular}


surface sediment $\mathrm{HgT}$ and $\mathrm{MeHg}$, respectively; 26\% for Morgo subsurface sediment $\mathrm{Hg}_{\mathrm{T}}$; and $10 \%$ for Primero $\mathrm{MeHg}$ ). A decrease is observed in the western basins (up to $-21 \%$ for Lignano surface sediment $\mathrm{Hg}_{\mathrm{T}},-45 \%$ for $\mathrm{S}$. Andrea subsurface sediment $\mathrm{Hg}_{\mathrm{T}}$, and $-16 \%$ and $-37 \%$ for S. Andrea surface and subsurface sediment $\mathrm{MeHg}$, respectively).

Overall, sediment concentrations in the water column are higher in the HwL than in the Ref simulation, promoting $\mathrm{Hg}$ and $\mathrm{MeHg}$ partitioning into sediment and decreasing $\mathrm{HgO}$ evasion ( $-26 \%$ with respect to Ref). In the HwL scenario, the overall mercury budget is changed by a net increase of $\mathrm{Hg}_{\mathrm{T}}$ outputs from the lagoon to the sea with respect to Ref.

The sediment recovery time was computed for the Ref simulation baseline scenario as the time required for surface sediment to reach the contamination level limit of $\mathrm{HgT}$ of $0.3 \mathrm{mg} / \mathrm{kg}$ set by Italian legislation under the EU-Water Framework Directive (Ministry of Environment Decree, 28/11/2010 n²60, WFD, 2000/ $60 \mathrm{EU})$.

Under baseline conditions, the averaged recovery time for all lagoon surface sediments (weighted over the surface of each box) is 570 years, ranging from 50 years in Morgo to 1040 years in Buso depending on initial concentrations and on transport and transformation processes acting on each sub-basin. The sub-surface sediment averaged recovery time is much longer (1250 years) and ranges from 108 years in Morgo to 1750 years in Lignano and Buso. With the simulation run fully removing $\mathrm{Hg}$ inputs at marine boundaries (NoM), $0.3 \mathrm{ppm}$ average concentrations in surface sediment are achieved 5 times faster relative to the Ref scenario, being reached after only 110 years.

Conversely, the removal of direct river mercury inputs from the simulation does not have a significant impact on average sediment recovery times.

\section{Discussion}

In this paper, we modelled the evolution of the mercury system in a hot spot of the Northern Adriatic Sea to project this system's evolution over the next 100 years while also considering climate change scenarios. The analysis was performed to contribute insight on relevant processes and on relative contributions of external boundaries and climatic conditions to overall budgets and dynamics. Hg budgets have been computed and compared for the scenarios, as reported in Fig. 6. In addition, a long term run was used to estimate the time required to reach sediment concentration values prescribed under environmental legislation. The model results highlight the relevance of the marine boundary to overall processes and, in particular, to mercury dynamics present in the water column, which are mainly driven by boundary conditions. However, the evolution of sediment concentrations is mainly driven by processes acting within the sediment and at the water/ sediment interface. Such processes include sediment resuspension/ deposition dynamics and methylation/demethylation processes, which in the model are, respectively governed in large part by water circulation dynamics and environmental conditions, and namely by temperature and solar radiation levels.

The model was applied in a 6-box configuration of the horizontal dimension. This configuration is more efficient than finer scale resolution models used, for instance, for the computation of water fluxes between boxes. It, thus, allows one to perform longterm scenario simulations. Another simplification commonly applied and accepted for model applications (Amos et al., 2014, 2015; Soerensen et al., 2010, 2016; Sunderland and Mason, 2007) pertains to the simple representation of $\mathrm{Hg}$ uptake by phytoplankton and its bioaccumulation in the trophic chain. Indeed, mechanisms of Hg uptake by phytoplankton are more complex in

\section{Hg budget for each scenario [kg/y]}

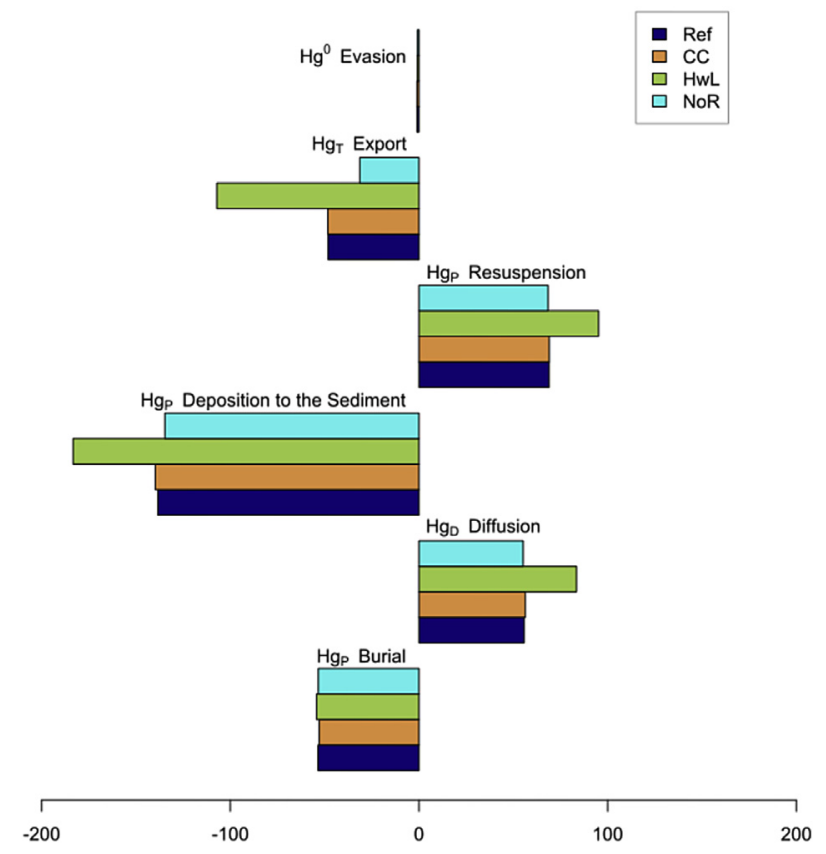

Fig. 6. Mass budget for HgT by the end of the 100 years simulations scenario (for the 4 scenarios: Ref, NoR, CC, and HwL).

reality (Le Faucheur et al., 2014). However, Sunderland et al. (2010) have shown that this process only contributes to a small portion of the overall budget in Passamaquoddy Bay. Despite its simplicity, the model allows one to identify major $\mathrm{Hg}$ lagoon dynamics and reproduce sediment deposition, erosion and burial processes. Comparisons drawn between monthly measures of dissolved mercury $\left(\mathrm{Hg}_{\mathrm{D}}\right)$ in the water column and with particulate $\mathrm{MeHg}$ $\left(\mathrm{MeHg}_{\mathrm{P}}\right)$ content in surface sediment have shown satisfactory agreement with field data (Melaku Canu et al., 2015). The model reproduced spatial variability between boxes and year-round temporal variability according to limits set by the model resolution, by the resolution (both in time and space) of field data, and by the time resolution of boundary conditions.

Results of the Ref simulation on long-term mercury budget trends in the Marano-Grado Lagoon show that sediment will continue to act as a secondary source of contamination in the long run. However, after 100 years of simulation conducted at the baseline, current $\mathrm{Hg}_{\mathrm{T}}$ concentrations in the surface and subsurface sediment levels will decrease, inducing a net decrease $(-57 \%)$ in $\mathrm{Hg}_{\mathrm{T}}$ export to the sea over time that will change from $112 \mathrm{~kg} / \mathrm{y}$ of the present state to $48 \mathrm{~kg} / \mathrm{y}$ over 100 years with a net future $\mathrm{MeHg}$ export level of $0.63 \mathrm{~kg} / \mathrm{y} . \mathrm{Hg}_{\mathrm{T}}$ concentrations in surface and subsurface sediment will slowly decrease overtime due to transport processes (e.g., burial in the deepest sediment and transferring to the water column followed by export to the Adriatic Sea or volatilization). The model predicts that surface sediment (the first $2 \mathrm{~cm}$ ) will be recovered in all sub-basins after 1000 years, but it will be 500 years more before concentrations decline in subsurface sediment (3-10 cm in depth). Interestingly, the decreasing trend observed for $\mathrm{Hg}_{\mathrm{T}}$ is decoupled from $\mathrm{MeHg}$ decontamination. After 100 years, the change in $\mathrm{MeHg}$ export will be almost negligible, with its formation and export related to environmental conditions and not limited by the predicted decrease in subsurface sediment $\mathrm{Hg}_{\mathrm{T}}$ concentrations.

Recovery times were computed assuming that boundary 
concentrations and global mercury dynamics do not change in the future. This is clearly an approximation based on the best data currently available and based on data and model collation. This estimate is not meant to be used as an official value but as information useful for determining the extent of historical mercury pollution based on a time-focused perspective.

However, an unbridgeable uncertainty regarding boundary and forcing condition values must be taken into account when considering such a long time frame, and such computations have only to be taken as broad indications of timescales of recovery and not as exact estimations of recovery time. Other set-ups could be developed if global mercury models (projecting overall changes in mercury circulation in a coupled ocean-atmospheric system based on future climatic and socio-economic scenarios) were available. Without such information, we prefer to use existing boundaries instead of drawing subjective assumptions on global trends while remembering that our scenario could be considered as precautionary because in the long run mercury inputs from the Isonzo River through the Adriatic Sea could decline considerably.

To apply a minimum (but unrealistic) limit to our computation of recovery time, a NoM simulation was run after removing $\mathrm{Hg}$ inputs at marine boundaries; this generated an average recovery time of only 110 years.

Conversely, the removal of direct river mercury inputs to the lagoon (NoR scenario) did not significantly change average sediment recovering times. The simulation allowed us to explore the effects of a hypothetical decontamination intervention on river basins (e.g., mercury capping) as an indication of the benefits of such an intervention for a given system. The model shows that riverine input removal has minimal effects on $\mathrm{Hg}_{\mathrm{T}}$ mercury concentrations in surface and subsurface sediments and the water column. Effects on MeHg concentrations are instead more evident in sediments and the water column as shown in Fig. 5. An overall effect, however, is found at the end of the 100-year simulation, with a decrease in mercury exports to the Adriatic Sea for Ref (35\% for $\mathrm{Hg}_{\mathrm{T}}$ and $94 \%$ for $\mathrm{MeHg}$ ) and with a reduction in $\mathrm{Hg}_{\mathrm{T}}$ concentrations in surface sediment as described above (exports of $\mathrm{Hg}_{\mathrm{T}}$ of $31 \mathrm{~kg} / \mathrm{y}$ and only of $0.04 \mathrm{~kg} / \mathrm{y}$ of $\mathrm{MeHg}$ ).

For the CC scenario, we assessed the effects of temperature increases on mercury dynamics in the Marano-Grado Lagoon without making any other assumptions on changes in $\mathrm{Hg}_{\mathrm{T}}$ concentrations at boundaries related to either temperature changes or socioeconomic scenarios. The net $\mathrm{MeHg}$ sea export level is slightly higher (by 3\%) while the $\mathrm{Hg}_{\mathrm{T}}$ export level is almost the same. Higher temperatures fuel higher bacterial metabolic rates that enhance methylation (and demethylation) activities. However, methylation prevails over demethylation, resulting in higher MeHg concentrations in surface and sub-surface sediments with potential effects on the trophic chain. Conversely, $\mathrm{Hg}_{\mathrm{T}}$ concentrations in sediments and water do not change significantly relative to Ref ones, being mainly driven by marine boundary values. The effects of increasing methylation and demethylation rates are much less significant in water column MeHg concentrations $(+0.17 \%)$ due to the effects of intense water circulation and exchanges with seawater. However, we speculate that temperature increases can lead to longer periods of stratification in shallow lagoon water, a condition that is known to promote bottom anoxia, to enhance diffusion from pore-water (Emili et al., 2014) and favour optimal zone shifting for methylation from sediments to the water column (Fitzgerald et al., 2007). Moreover, increasing temperatures can induce an increase in $\mathrm{MeHg}$ levels in surrounding coastal systems, including at river mouths. Therefore, our set up may underestimate $\mathrm{MeHg}$ concentrations in the lagoon. In addition, our representation of sediment-water transport could be somewhat underestimated for all scenarios due to model limitations concerning the following: 1) the use of a partition constant $\left(K_{D}\right)$ fixed in time and space and 2) the use of Fick's law to calculate diffusion processes that often cause underestimations of in-situ fluxes measured within a benthic chamber (Benoit et al., 1999).

When removing boundary inputs, $\mathrm{MeHg}$ concentrations in water decrease dramatically ( $-79 \%$ in the NoM scenario, and $-31 \%$ in the NoR scenario), and concentrations in surface and subsurface sediment decrease as well. This allows us to infer that riverine and marine inputs of $\mathrm{Hg}$ and $\mathrm{MeHg}$ play a key role in the accumulation of $\mathrm{MeHg}$ in sediment. In their absence, $\mathrm{MeHg}$ produced in sediment should be partly counterbalanced by demethylation and transport to the water column (followed by export, photo-degradation or deposition back to sediment). Marine boundary concentrations are clearly the main drivers shaping mercury dynamics in the MaranoGrado lagoon system and corresponding self-decontamination rates. As shown above, river inputs have a minor effect but are still important, and especially when considering net mercury fluxes between the lagoon and its boundary systems.

The sea level rise and increasing levels of water exchange at inlets tend to intensify all transfer processes directly related to water circulation. By the end of the 100-year run, the HwL shows (with respect to the Ref) an increase in $\mathrm{Hg}_{\mathrm{T}}$ export towards the sea $(+122 \%)$, diffusion $(+48 \%)$, resuspension $(+38 \%)$ and deposition $(+32 \%)$. A minor change in burial rates is also observed. Despite negligible changes in water concentrations, $\mathrm{MeHg}$ and $\mathrm{Hg}_{\mathrm{T}}$ levels in sediment increase by $7 \%$ and $15 \%$, respectively, thus potentially increasing in biota as well. As both CC and HwL show an increase in $\mathrm{MeHg}$ concentrations in surface sediment, combined effects of sea level rise and temperature increases should reasonably lead to conditions of increased toxicity for local biota.

\section{Conclusion}

The Marano Grado lagoon is a large Mediterranean hot spot for mercury contamination. The lagoon has been receiving mercury discharge for centuries, and even if inputs from anthropogenic sources stopped decades ago, the lagoon's sediments still present high mercury concentrations and act as a secondary source for the whole Mediterranean basin. A scenario analysis performed based on a validated numerical model constrained by available data and information allowed us to assess short- and long-term dynamics of mercury contamination in this system. The model shows that based on the current configuration, 100 years from now, a decrease in $\mathrm{Hg}_{\mathrm{T}}$ concentrations is expected in the system. Similarly, there should be an overall decrease in mercury flux within the lagoon system and between the lagoon and its surrounding boundaries. However, a general increase in $\mathrm{MeHg}$ is expected, and particularly in surface sediment (73\%). Climate change should worsen this situation, causing increases in $\mathrm{MeHg}$ concentrations of up to $87 \%$ and $95 \%$ of current levels with respect to increasing temperatures $\left(+2.5^{\circ} \mathrm{C}\right)$ and sea level rise $(0.315 \mathrm{~m})$, respectively. Accordingly, mercury bioaccumulation in biota is expected to increase in the future.

Our simulation suggests that a complete removal of mercury inputs from rivers directly discharging into this lagoon would not substantially affect mercury dynamics besides reducing $\mathrm{MeHg}$ concentrations in water (12\%) and surface sediments (6\%). Interestingly, the reduction in $\mathrm{MeHg}$ as a consequence of the total removal of $\mathrm{Hg}$ inputs from rivers is of the same order as $\mathrm{MeHg}$ increase resulting from an increase in temperature or from sea level rise; therefore, the former may be envisaged as a possible way of mitigating adverse effects of the latter.

The long-term run of the baseline reference simulation indicates that recovery times of lagoon sediments computed as the time required to decrease $\mathrm{Hg}_{\mathrm{T}}$ to $0.3 \mathrm{mg} / \mathrm{kg}$ are roughly 600 years for 
surface sediments and 1200 years for sub-surface sediments. These lengths of time should be markedly shorter ( 110 years for sediment) for unrealistic scenarios involving no $\mathrm{Hg}$ inputs from the sea. Though unrealistic, such scenarios still offer a timescale for waste remediation measures needed for the system and serve as a framework for understanding this ecosystem service.

\section{Acknowledgements}

This research was carried out with contributions from the RITMARE flagship Project and with the contribution from the Friuli Venezia Giulia Regional Protection Agency (ARPA-FVG) in the frame of the EU-SHAPE project activities.

\section{References}

Acquavita, A., Covelli, S., Emili, A., Berto, D., Faganeli, J., Giani, M., Horvat, M. Koron, N., Rampazzo, F., 2012. Mercury in the sediments of the Marano and Grado Lagoon (northern Adriatic sea): sources, distribution and speciation. Estuar. Coast. Shelf Sci. 113, 20-31.

Amos, H.M., Jacob, D.J., Kocman, D., Horowitz, H.M., Zhang Y, Dutkiewicz, S. Horvat, M., Corbitt, E.S., Krabbenhoft, D.P., Sunderland, E.M., 2014. Global biogeochemical implications of mercury discharges from rivers and sediment burial. Environ. Sci. Technol. 48, 9514-9522.

Amos, H.M., Sonke, J.E., Obrist, D., Robins, N., Hagaìn, N. Horowitz, H.M. Mason, R.P., Witt, M., Hedgecock, I.M., Corbitt, E.S., Sunderland, E.M., 2015. Environ. Sci. Technol. 49 (7), 4036-4047.

Balcom, P.H., Scartup, A.T., Mason, R.P., Chen, C.Y., 2015. Sources of water column methylmercury across multiple estuaries in the Northeast U.S. Mar. Chem. 177, 721-730.

Benoit, J.M., Gilmour, C.C., Mason, R.P., Heyes, A., 1999. Sulfide controls on mercury speciation and bioavailability to methylating bacteria in sediment pore waters. Environ. Sci. Technol. 33 (6), 951-957.

Bloom, N.S., Moretto, L.M., Scopece, P., Ugo, P., 2004. Seasonal cycling of mercury and monomethyl mercury in the Venice Lagoon (Italy). Mar. Chem. 91, 85-99.

Canu, M.D., Solidoro, C., Cossarini, G., Giorgi, F., 2010. 2010 Effect of global change on bivalve rearing activity and the need for adaptive management. Clim. Res. 42, $13-26$.

Canu, D.M., Acquavita, A., Knightes, C.D., Mattassi, G., Scroccaro, I., Solidoro, C., 2012. Modeling the mercury cycle in the marano-Grado Lagoon (Italy). In: Models of the Ecological Hierarchy: from Molecules to the Ecosphere. Elsevier B.V., pp. 239-257

Car, J., Dizdarević, T., 2004. Written reports on the effects of mining activities on the natural environment in Idrija in the 19th century. In: Winkler Prins, C.F., Donovan, S.K. (Eds.), Scripta Geologica Special Issue, vol. 4. 6, pp. 35-44 (Leiden).

Cossarini, G., Libralato, S., Salon, S., Gao, X., Giorgi, F., Solidoro, C., 2008. Downscaling experiment for the Venice lagoon. II. Effects of changes in precipitation on biogeo- chemical properties. Clim. Res. 38, 43-59.

Covelli, S., Faganeli, J., De Vittor, C., Predonzani, S., Acquavita, A., Horvat, M., 2008. Benthic fluxes of mercury species in a lagoon environment (Grado Lagoon, northern Adriatic sea, Italy). Appl. Geochem 23, 529-546.

Covelli, S., Langone, L., Acquavita, A., Piani, R., Emili, A., 2012. Historical flux of mercury associated with mining and industrial sources in the Marano and Grado Lagoon (northern Adriatic Sea). Estuar. Coast. Shelf Sci. 113, 7-19. http:// dx.doi.org/10.1016/j.ecss.2011.12.038.

Dalla Valle, M., Codato, E., Marcomini, A., 2007. Climate change influence on POPs distribution and fate: a case study. Chemosphere 67 (7), 1287-1295.

Dizdarevič, T., 2001. The influence of mercury production in Idrija mine on the environment in the Idrija region and over a broad area. RMZ-Mater. Geoenviron 48, 56-64.

Dorigo, L., 1965. La Laguna di Grado e le sue foci. Uff. Idrogr. del Magistr. della Acque 155.

Emili, A., Carrasco, L., Acquavita, A., Covelli, S., 2014. A laboratory-incubated redox oscillation experiment to investigate $\mathrm{Hg}$ fluxes from highly contaminated coastal marine sediments (Gulf of Trieste, Northern Adriatic Sea). Environ. Sci. Pollut. Res. 21 (6), 4124-4133.

Faganeli, J., Hines, M.E., Horvat, M., Falnoga, I., Covelli, S., 2014. Methylmercury in the gulf of Trieste (Northern Adriatic sea): from microbial sources to seafood consumers. Food Technol. Biotechnol 52, 188-197.

Ferrarin, C., Umgiesser, G., Bajo, M., Bellafiore, D., De Pascalis, F., Ghezzo, M., Mattassi, G., Scroccaro, I., 2010. Hydraulic zonation of the lagoons of Marano and Grado, Italy. A Model. approach. Estuar. Coast. Shelf Sci. 87, 561-572.

Fitzgerald, W.F., Lamborg, C.H., Hammerschmidt, C.R., 2007. Marine biogeochemical cycling of mercury. Chem. Rev. 107, 641-662.

Gnamuš, A., Horvat, M., 1999. Mercury in terrestrial food webs of the Idrija mining area. In: Ebinghaus, R., Turner, R.R., de Lacerda, L.D., Vasiliev, O., Salomons, W. (Eds.), Mercury Contaminated Sites: Characterization, Risk Assessment and Remediation. Springer Berlin Heidelberg, Berlin, Heidelberg, pp. 281-320. http://dx.doi.org/10.1007/978-3-662-03754-6_16.
Gosar, M., 2008. Mercury in river sediment, floodplains and plants Growing thereon in frainage area of irrija mine, Slovenia. Pol. J. Environ. Stud 17 (2), 227-236.

Gosar, M., Teršič, T., 2015. Contaminated sediment loads from ancient mercury ore roasting sites, Idrija area, Slovenia. J. Geochem. Explor 149, 97-105. http:// dx.doi.org/10.1016/j.gexplo.2014.11.012.

Hammerschmidt, C.R., Fitzgerald, W.F., 2004. Geochemical controls on the production and distribution of methylmercury in near-shore marine sediments. Environ. Sci. Technol. 38, 1487-1495.

Harley, C.D.G., Hughes, A.R., Hultgren, K.M., Miner, B.G., others, 2006. The impacts of climate change in coastal marine systems. Ecol. Lett. 9, 228-241.

Hines, M.E., Poitras, E.N., Covelli, S., Faganeli, J., Emili, A., Žižek, S., Horvat, M., 2012. Mercury methylation and demethylation in Hg-contaminated lagoon sediments (Marano and Grado Lagoon, Italy). Estuar. Coast. Shelf Sci. 113, 85-95.

Horvat, M., Kotnik, J., Logar, M., Fajon, V., Zvonarić, T., Pirrone, N., 2003. Speciation of mer cury in surface and deep-sea waters in the Mediterranean Sea. Atmos. Environ. 37 (Suppl. 1), 93-108.

Lambeck, K., Antonioli, F., Ferranti, L., Leoni, G., Scicchitano, G., Silenzi, S., 2011. Sea level change along the Italian coast during the Holocene and projections for the future. Quat. Int. 232, 250-257.

Lazzari, P., Mattia, G., Solidoro, C., Salon, S., Crise, A., Zavatarelli, M., Oddo, P. Vichi, M., 2013. The impacts of climate change and environmental management policies on the trophic regimes in the Mediterranean Sea: scenario analyses. J. Mar. Syst. 135, 137-149. http://dx.doi.org/10.1016/j.jmarsys.2013.06.005.

Le Faucheur, S., Campbell, P.G.C., Fortin, C., Slaveykova, V.I., 2014. Global mercury partnership. Interactions between mercury and phytoplankton: speciation, bioavailability, and internal handling. Environ. Toxicol. Chem. 33 (6) 1211-1224.

Melaku Canu, D., Umgiesser, G., Solidoro, C., 2001. Short term simulations under winter conditions in the lagoon of Venice: a contribution to the environmental impact assessment of a temporary closure of the inlets. Ecol. Model. 138 (1-3), 215-230.

Melaku Canu, D., Rosati, G., Solidoro, C., Heimbürger, L.-E., Acquavita, A., 2015 A comprehensive assessment of the mercury budget in the Marano-Grado Lagoon (Adriatic Sea) using a combined observational modeling approach. Mar. Chem. 177, 742-752. http://dx.doi.org/10.1016/j.marchem.2015.10.013.

Monperrus, M., Tessier, E., Amouroux, D., Leynaert, A., Huonnic, P., Donard, O.F.X. 2007. Mercury methylation, demethylation and reduction rates in coastal and marine sur- face waters of the Mediterranean Sea. Mar. Chem. 107, 49-63.

Nakicenovic, N., Swart, R. (Eds.), 2000. Special Report on Emissions Scenarios. A Special Report of Working Group III of the Intergovernmental Panel on Climate Change. Cambridge University Press, Cambridge, UK.

Pato, P., Lopes, C., Válega, M., Lillebø, A.I., DiasJ.M, Pereira E., Duarte, A.C., 2008. Mercury fluxes between an impacted coastal lagoon and the Atlantic Ocean. Estuarine. Coast. Shelf Sci. 76 (4, 1), 787-796.

Rajar, R., Žagar, D., Širca, A., Horvat, M., 2000. Three-dimensional modelling of mercury cycling in the Gulf of Trieste. Sci. Total Environ. 260, 109-123. http:// dx.doi.org/10.1016/S0048-9697(00)00555-6.

Regione FVG, 2013. Attività sperimentali di monitoraggio del trasporto sedimentario alle bocche tidali della Laguna di Marano e Grado.

Rothenberg, S.E., Ambrose, R.F., Jay, J.A., 2008. Mercury cycling in surface water pore water and sediments of Mugu Lagoon, CA, USA. Environ. Pollut. 154, $32-45$.

Sharif, A., Tessier, E., Bouchet, S., Monperrus, M., Pinaly, H., Amouroux, D., 2013 Comparison of different air-water gas exchange models to determine gaseous mercury evasion from different european coastal lagoons and estuaries. Water Air, Soil Pollut. 224 (7).

Soerensen, A.L., Sunderland, E.M., Holmes, C.D., Jacob, D.J., Yantosca, R.M., Skov, H., Christensen, J.H., Strode, S.A., Mason, R.P., 2010. An improved global model for air-sea exchange of mercury: high concentrations over the North Atlantic. Environ. Sci. Technol. 44 (22), 8574-8580.

Soerensen, A.L., Schartup, A.T., Gustafsson, E., Gustafsson, B.G., Undeman, E. Björn, E., 2016. Eutrophication increases phytoplankton methylmercury concentrations in a Coastal Sea - A Baltic Sea case study. Environ. Sci. Technol. 50 (21), 11787-11796.

Solidoro, C., Cossarini, G., Libralato, S., Salon, S., 2010. Remarks on the redefinition of system boundaries and model parameterization for downscaling experiments. Prog. Oceanogr. 84, 134-137.

Sorokin, Y.I., Sorokin, P.Y., Giovanardi, O., Dalla Venezia, L., 1996. Study of the ecosystem of the lagoon of Venice, with emphasis on anthropogenic impact. Mar. Ecol. Prog. Ser. 141, 247-261.

Sprovieri, M., Oliveri, E., Di Leonardo, R., Romano, E., Ausili, A., Gabellini, M. Barra, M., Tranchida, G., Bellanca, A., Neri, R., Budillon, F., Saggiomo, R. Mazzola, S., Saggiomo, V., 2011. The key role played by the Augusta basin (southern Italy) in the mercury contamination of the Mediterranean Sea. J. Environ. Monit. 13, 1753-1760.

Sunderland, E.M., Mason, R.P., 2007. Human impacts on open ocean mercury concentrations. Global Biogeochem. Cycles 21 (4).

Sunderland, E.M., Dalziel, J., Heyes, A., Branfireun, B.A., Krabbenhoft, D.P. Gobas, F.A.P.C., 2010. Response of a macrotidal estuary to changes in anthropogenic mercury loading between 1850 and 2000. Environ. Sci. Technol. 44, 1698-1704.

Thompson, J.R., Flower, R.J., 2009. Environmental science and management of coastal lagoons in the southern mediterranean region: key issues revealed by the MELMARINA project. Hydrobiologia 622 (1), 221-232.

US EPA, 1988. Water Qual. Simul. program 5 manual. (Ambrose R). 
US EPA, 2009. Water Qual. Simul. Program 6 (manual. Wool T. A., Ambrose R. B.,Martin J.L., Comer E. A).

Vost, E.E., Amyot, M., O'Driscoll, N.J., 2012. Photoreactions of mercury in aquatic systems. In: Liu, G., Cai, Y., O'Driscoll, N. (Eds.), Environmental Chemistry and Toxicolgy of Mercury. Wiley ed. JOHNWILEY \& SONS, INC, pp. 193-218.

Whalin, L., Kim, E.-H., Mason, R., 2007. Factors influencing the oxidation, reduction, methylation and demethylation of mercury species in coastal waters. Mar. Chem. 107, 278-294.

Wool, T.A., Ambrose, R.B., Martin, J.L., Comer, E.A., 2001. Water Quality Analysis
Simulation Program (WASP) Version 6.0: User's Manual.

Zagar, D., Knap, A., Warwick, J.J., Rajar, R., Horvat, M., Cetina, M., 2006. Modelling of mercury transport and transformation processes in the Idrijca and Soca river system. Sci. Total Environ. 368, 149-163. http://dx.doi.org/10.1016/ j.scitotenv.2005.09.068.

Žagar, D., Petkovšek, G., Rajar, R., Sirnik, N., Horvat, M., Voudouri, A., Kallos, G. Cetina, M., 2007. Modelling of mercury transport and transformations in the water compartment of the Mediterranean Sea. Mar. Chem. 107, 64-88.

Please cite this article in press as: Canu, D., Rosati, G., Long-term scenarios of mercury budgeting and exports for a Mediterranean hot spot (Marano-Grado Lagoon, Adriatic Sea), Estuarine, Coastal and Shelf Science (2017), http://dx.doi.org/10.1016/j.ecss.2016.12.005 